\title{
AtMYB7 Acts as a repressor of lignin biosynthesis in Arabidopsis
}

\author{
Won-Chan Kim ${ }^{1}$ (D) \\ 애기장대 MYB7 유전자의 리그닌 생합성 억제 조절
}

\section{김 원 찬 ${ }^{1}$}

Received: 22 April 2016 / Accepted: 17 May 2016 / Published Online: 30 September 2016

(C) The Korean Society for Applied Biological Chemistry 2016

\begin{abstract}
Secondary cell wall is the most abundant biomass produced by plants. Plant secondary cell wall is composed of a complex mixture of cellulose, hemicellulose, and lignin. Lignin, a phenolic polymer that hinders the degradation of cell wall polysaccharides to simple sugars destined for fermentation to bioethanol. Cell wall biosynthesis pathway-specific biomass engineering offers an attractive 'genetic pretreatment' strategy to improve bioenergy feedstock. Recently, we found a transcription factor, MYB7, which is a transcriptional switch that may turns off the genes necessary for lignin biosynthesis. To gain insights into MYB7 mediated transcriptional regulation, we first established a dominant suppression system in Arabidopsis by expressing MYB7-SRDX. Then we used a transient transcriptional activation assay to confirm that MYB7 suppress the transcription of the lignin biosynthetic gene. Taken together, we conclude that MYB7 function as a repressor of the genes involved in the lignin biosynthesis.
\end{abstract}

Keywords Bioethanol · Lignin · MYB7 · Secondary wall biosynthesis - Transcriptional regulation

Won-Chan $\operatorname{Kim}(\bowtie)$

E-mail:kwc@knu.ac.kr

${ }^{1}$ School of Applied Biosciences, Kyungpook National University, Daegu 41566, Republic of Korea

This is an Open Access article distributed under the terms of the Creative Commons Attribution Non-Commercial License (http://creativecommons. org/licenses/by-nc/3.0/) which permits unrestricted non-commercial use, distribution, and reproduction in any medium, provided the original work is properly cited.

\section{서 론}

최근 들어 화석연료를 대체하기 위한 신재생 에너지 개발에 관 한 노력이 세계 각국에서 고조되고 있는 상황에서 바이오매스 에 저장된 탄수화물을 이용하여 바이오 에탄올과 같은 신재생 액체연료를 생산하려는 연구에 관심이 집중되고 있다. 그러나 현재의 생산기술 시스템으로는 브라질을 제외한 대부분의 국가 에 있는 바이오 에탄올의 연료로서의 경쟁력은 국가보조를 의 지하지 않고는 불가능한 현실이다. 바이오 에탄올 생산가의 약 $20 \%$ 정도가 원료 비용임을 고려하면, 옥수수나 다른 일반 작 물과 같은 높은 가격의 원료를 사용하기보다는 획기적으로 저 렴한 가격의 셀룰로식 바이오매스를 원료로 이용하면 전체 바 이오 에탄올 생산가를 현저하게 낮출 수 있을 것이며 가솔린과 의 가격경쟁에서도 경쟁력을 갖출 수 있게 될 것이다(Kang 등, 2014).

셀룰로식 바이오매스는 식물체가 자연생태로부터 받는 환경 적인 스트레스나 곤충, 동물 또는 병원균 등으로부터의 공격을 방어하기 위한 메커니즘으로 설계되고 만들어져서 발효 균주가 셀룰로식 바이오매스에 저장된 발효 가능한 글루코스에 접근하 기 어렵게 되어있다. 이러한 바이오매스를 전처리 없이 사용하 면 에탄올 생산의 수율이 낮아지게 된다(Himmel 등, 2007). 이 를 극복하기 위한 방법으로는 첫째, 다양한 화공학적인 바이오 매스 전처리 기술들을 이용하여 셀룰로식 바이오매스를 전처리 하므로 발효 가능한 글루코스의 함량을 증가시키는 방법으로 상 당한 성과를 거두고 있다(Seo 등, 2008). 둘째, 바이오매스 원 료의 재배조건이나 유전적인 형질을 변형하여 셀룰로식 바이오 매스 중 리그닌 함량을 낮추거나 셀룰로스를 분해하여 발효 가 능한 글루코스를 생산하는데 장애가 되는 요소들을 최소화 및 최적화하는 방법이다.

식물의 이차생장의 결과로 생산되는 바이오매스의 대부분은 식물의 이차세포벽에 축적된다. 식물의 이차세포벽은 크게 셀룰 로스, 헤미셀룰로스, 리그닌이라는 3 가지 물질로 구성되며 이들 
중 페놀성 복합 화학 물질인 리그닌은 셀룰로스나 헤미셀룰로 스와 달리 알코올 발효과정의 저해 물질로서 바이오매스를 발 효공정에 투입하기 전에 리그닌을 제거하는 과정을 거치는 것 이 중요하다(Alvira 등, 2010). 이 과정에 사용되는 에너지가 전 체 바이오 에탄올 생산비에서 차지하는 비중이 크기 때문에 리 그닌 함량이 적거나 제거가 쉬운 형태의 리그닌을 가진 바이오 매스의 생산이 절실히 필요한 상태이다. 따라서, 식물의 이차세 포벽 생합성의 과정을 조절함으로 전체 바이오매스의 생산량과 조성을 바이오 에너지 생산을 위해 최적 조건으로 조절함으로 써 바이오 에탄올 생산을 최대화할 수 있을 것이다. 최근 들어 특정 전사조절 인자들이 xylem이나 phloem의 생성에 관여한다 는 보고들이 있으며 전사조절인자들의 발현을 조절하여 식물의 이차생장 과정에서 바이오매스 생합성 조절이 가능하다고 이야 기하고 있다(Kubo 등, 2005; Ko 등, 2007; Kim 등, 2014).

본 연구에서는 모델 식물인 애기장대의 MYB7 전사조절 인 자에 대한 특성을 확인한 논문으로 $\mathrm{MYB} 7$ 전사조절 단백질이 리그닌 생합성을 억제 조절한다는 것을 확인하였다. 이는 에너 지 작물 개발 분야에서는 저 리그닌 또는 추출이 쉬운 리그닌 을 가진 작물의 개발 및 효소들이 쉽게 접근이 가능한 셀룰로 스나 헤미셀룰로스 함량을 증대시킨 작물 개발에 도움이 될 것 으로 생각된다.

\section{재료 및 방법}

\section{식물재료}

애기장대 야생형(Col-0)을 실험에 사용하였고, MYB7 knockout 종자는 Arabidopsis Biological Resource Center (ABRC)로부터 분양 받아 사용하였다. 애기장대는 생장상 $(16$ 시간 명처리/8시간 암처리)에서 온도는 $23-21{ }^{\circ} \mathrm{C}$ 상대습도는 $60 \%$ 로 유지하며 생 육시켰다.

\section{벡터 제작 및 식물 형질전환}

애기장대의 잎으로부터 RNeasy mini kit (Qiagen, Hilden, Germany)을 이용하여 total RNA를 분리하였다. 이렇게 준비된 total RNA를 SuperScript ${ }^{\mathbb{R}}$ II (invittrogen, Carlsbad, CA, USA) 역전사효소를 이용하여 cDNA를 합성하였다. MYB7 (At2g16720) 과발현체의 경우 합성된 $\mathrm{cDNA}$ 를 주형으로 $\mathrm{MYB} 7$ 영역을 $\mathrm{PCR}$ 로 증폭하여 pCB302-3 벡터(Xiang 등, 1999)에 삽입하여 제조 합 벡터를 제작하였다. MYB7-SRDX 과발현체의 경우는 MYB7 과발현체와 동일 방법으로 제작하되 말단부위에 정지코돈을 없 애주고 그대신 거기에 7개의 아미노산(LDLELRL)을 추가로 연 결해주어 사용하였다. 위의 방법으로 제작된 제조합 벡터들은 아그로박테리움(GV3101)을 이용하여 애기장대 내로 형질전환 시켰다. 대조구로 사용한 MYB46 과발현체는 본 연구진이 기 존에 제작해둔 과발현체를 사용하였다(Ko 등, 2009; Kim 등, 2013).

\section{식물 조직 관찰}

식물체 잎에서 리그닌 축적을 조사하기 위한 공초점 형과 이미 지 측정은 Olympus사(Center Valley, PA, USA)의 FV1000 모 델 현미경을 사용하였다. 일반 상토에서 3 주간 생육 시킨 애기
장대 잎을 이용하여 $514 \mathrm{~nm}$ 의 여기(Excitation) 파장 및 519$950 \mathrm{~nm}$ 범위의 방출(Emission)파장을 조사하여 형광 이미지를 획득하였다. 상기의 방법으로 잎에 분포되어있는 리그닌의 변화 정도를 자체형광(autoflruoresece)의 형광 발현을 통하여 확인하 였다. 식물체 줄기에서 리그닌 축적을 조사하기 위한 이미지 측 정은 Leica사(Wetzlar, Germany)의 DM500 모델 광학현미경을 사용하였다. 일반 상토에서 8주간 생육 시킨 애기장대의 줄기 횡단면 부위를 면도칼로 절단하고 여기에 $2 \%$ Phloroglucinol$\mathrm{HCl}$ 로 1 분간 염색시키고 이를 광학현미경을 통하여 관찰하였다.

\section{Transcriptional activation analysis}

애기장대로부터 protoplast의 준비 및 reporter 및 effector 벡터 의 protoplast 내부로의 삽입은 $\mathrm{Kim}$ 등(2013)의 방법에 따라 실 시하였다. Effector 벡터의 구축을 위하여는 MYB7 및 MYB46 의 $\mathrm{cDNA}$ 를 $\mathrm{CaMV} 35 \mathrm{~S}$ 프로모터 하류에 삽입시켰고, reporter 벡터는 4CL1 프로모터를 GUS 리포터 유전자 상류에 삽입하여 제작하였다. 4주간 생육시킨 애기장대 잎으로부터 분리한 Protoplast에 상기에 제작된 effector 및 reporter 벡터를 동시에 형질전환 시키고 상온에서 16시간 반응시킨 후 GUS 단백질에 의한 4-Methylumbelliferyl $\beta$-D-galactopyranoside의 분해 양상을 관찰하였다. 이때 GUS 단백질에 의한 분해 산물인 4-methylumbelliferone은 Hoefer Scientific사(Holliston, MA, USA)의 HIS $\mathrm{TKO} 100$ 모델로 측정하였다.

\section{결과 및 고찰}

\section{MYB7 전사조절 인자에 의한 식물의 표현형 양상}

MYB7 전사조절 인자의 특성을 알아보기 위하여 MYB7 과발 현 식물체 및 식물의 전사조절에서 하위 특정 유전자의 발현을 저해시키는 것으로 잘 알려진 $\mathrm{SRDX}$ 를 포함한 MYB7-SRDX를 제작하였다. SRDX 식물체의 제작은 EAR motif (5'-CTG GAT CTA GAA CTC CGT TTG TAA-3'을 정지코돈을 제거하고 삽입하여 제작하였다(Kagale과 Rozwadowski 2011). Ethyleneresponsive element binding factor associated amphiphilic repression (EAR)는 최근 개발된 식물 유전자의 조절방법으로 EAR motif를 목적하는 전자조절인자에 융합시킨 식물체는 그 전사조절인자 하위의 유전자의 발현을 억제하는 것으로 잘 알 려져 있다(Kagale과 Rozwadowski 2011). 제작된 식물체들의 표 현형을 살펴본 결과 MYB7 과발현 체에서는 외관표현형이 나 타나지 않았고, MYB7-SRDX 과발현 체에서는 식물체의 잎이 말리는 현상을 관찰할 수 있었다(Fig. 1). 이 결과는 대조 구로 사용한 MYB46 과발현 체의 표현형과 같은 것으로 일반적인 조건에서 식물의 잎에는 리그닌의 함량이 많지 않은 데 반하여 식물체 잎에 과량의 리그닌이 축적되었을 때 나타나는 표현형 으로(Ko 등, 2009; Kim 등, 2013), MYB7 전사조절인자가 식 물 체내 리그닌의 축적과 밀접한 관계가 있음을 보여주며, 특 히 MYB7 유전자가 하위 유전자를 조절할 수 없을 때 리그닌 의 함량이 증가하는 것으로 보아 MYB7 전사조절인자는 식물 체에서 리그닌 생합성을 억제 조절하는 것으로 생각된다. 이 결 과는 Jin 등(2000)에 의하여 보고된 MYB7의 상동 단백질인 $\mathrm{MYB} 4$ 가 UV 조사 하에서 이에 대한 방어 작용으로 리그닌을 


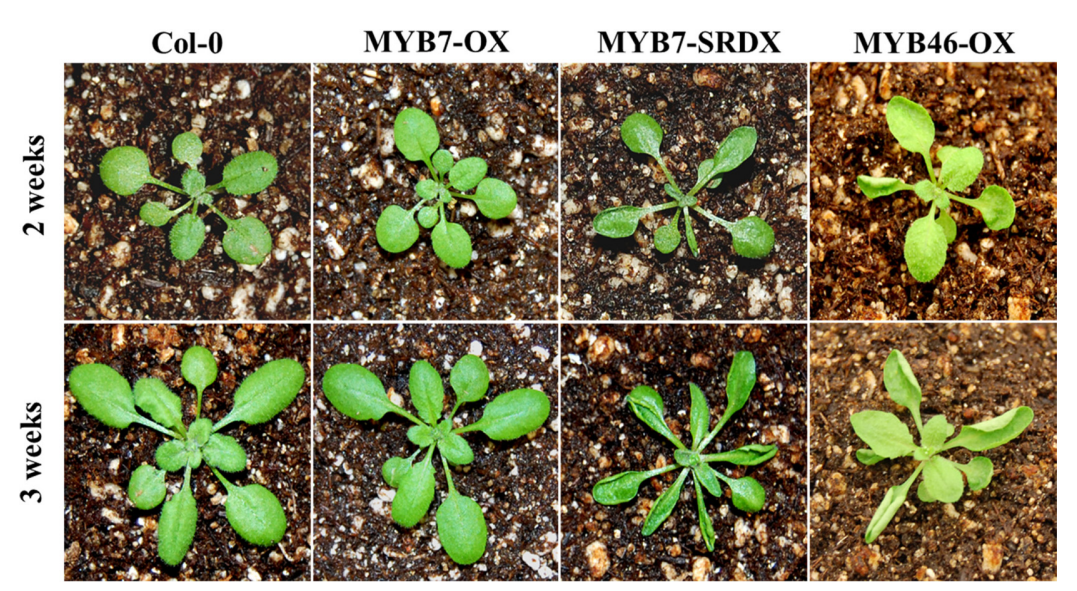

Fig. 1 Leaf phenotype analysis of wild-type and mutant plants. The MYB7-SRDX over-expression line show a leaf curling phenotype. Col-0, wild-type Arabidopsis (control); MYB7-OX, MYB7 over-expression transgenic plant; MYB7-SRDX, 35S:MYB7-SRDX over-expression transgenic plant; MYB46-OX, MYB46 over-expression transgenic plant (positive control)

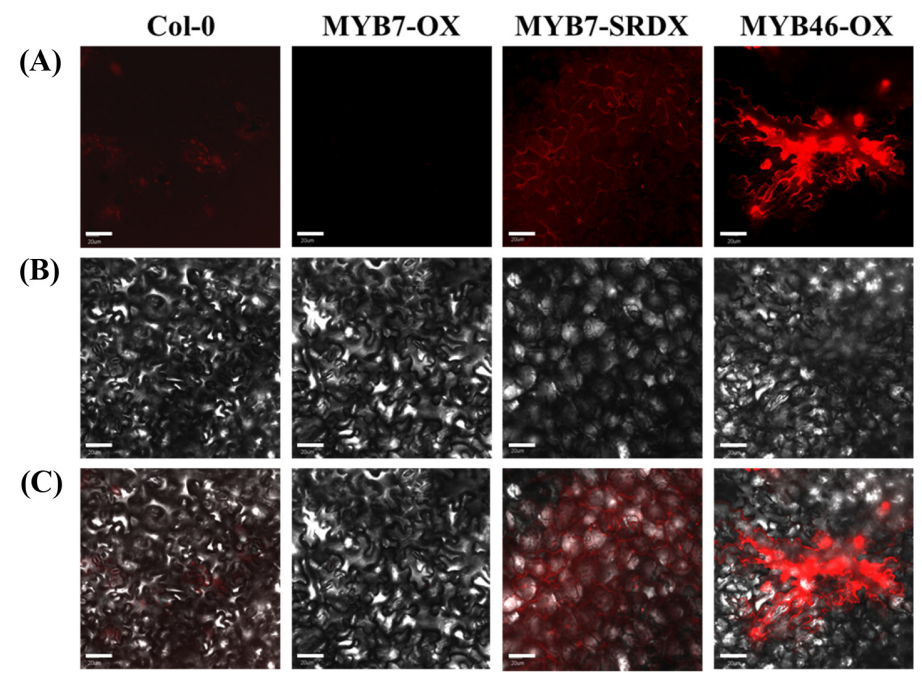

Fig. 2 Over-expression of MYB7-SRDX results in ectopic deposition of lignin in Arabidopsis mesophyll cell. Leaves from 3-week-old plants were examined for ectopic deposition of lignified secondary walls by collecting lignin autofluorescence images. Scale bars $=40 \mu \mathrm{m}$. The data were collected using a FV1000 (Olympus). Cell images were obtained using an excitation $514 \mathrm{~nm}$ and a bandpass (519-650 nm) emission filter. (A), lignin autofluorescence signal images; (B), bright-field images; (C), merged images. Col-0, wild-type Arabidopsis (control); MYB7-OX, MYB7 overexpression transgenic plant (negative control); MYB7-SRDX, 35S:MYB7-SRDX transgenic plant; MYB46-OX, MYB46 over-expression transgenic plant (positive control)

체내에 축적한다는 결과와 일치하는 결과이다.

\section{공초점 현미경을 이용한 식물 체내 리그닌 조사}

MYB7 전사조절인자에 의한 식물체의 외형 변화가 리그닌의 축 적에 의한 표현형인지를 확인하기 위하여 공초점 현미경을 이 용하여 MYB7 유전자 변이 식물체들에 대한 조사를 실시하였 다. 공초점 현미경을 이용하여 식물의 잎에 특정파장영역에서 관찰할 경우 리그닌의 함량에 따라 자체형광(autofluorescence) 을 발하는 정도가 달라지는 것으로 알려져 있다(Zhong 등, 2007). 이러한 특성을 이용하여 리그닌의 변화 정도를 관찰하였 다. 생육 3 주 된 애기장대의 잎에 존재 하는 리그린의 변화 정 도를 조사한 결과 MYB7 과발현 식물체에서는 야생형 애기장 대(Col-0) 보다 더 작은 자체형광을 나타내어 리그린이 상대적
으로 줄어든 것으로 판단되었고, 위의 실험결과와 같이 MYB7$\mathrm{SRDX}$ 과발현 식물체의 잎에서는 자체형광의 정도가 야생형 애 기장대보다 많아 리그린의 상대적인 양이 더 많이 축적됨을 확 인하였다(Fig. 2). 이상의 결과로 미루어 전사조절인자인 MYB7 은 식물의 잎에서 리그닌의 생합성을 억제한다는 것을 재확인 할 수 있었다.

\section{In vivo transient activity assay}

잎에서의 표현형과 공초점 현미경을 통한 리그닌의 축적 및 감 소를 확인하고 후 이러한 현상이 MYB7 전사조절인자 하위에 존재하는 리그닌 생합성 유전자에 영향을 미쳐서인지를 확인하 기 위하여 애기장대 잎으로부터 추출한 protoplast를 이용하여 in vivo transient activity assay를 실시하였다. 4주 생육한 애기 
(A) Effector

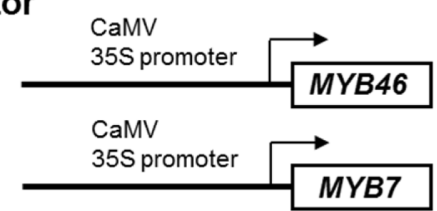

\section{Reporter}

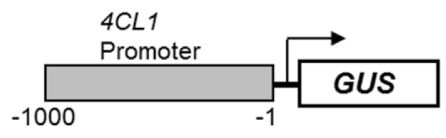

(B)

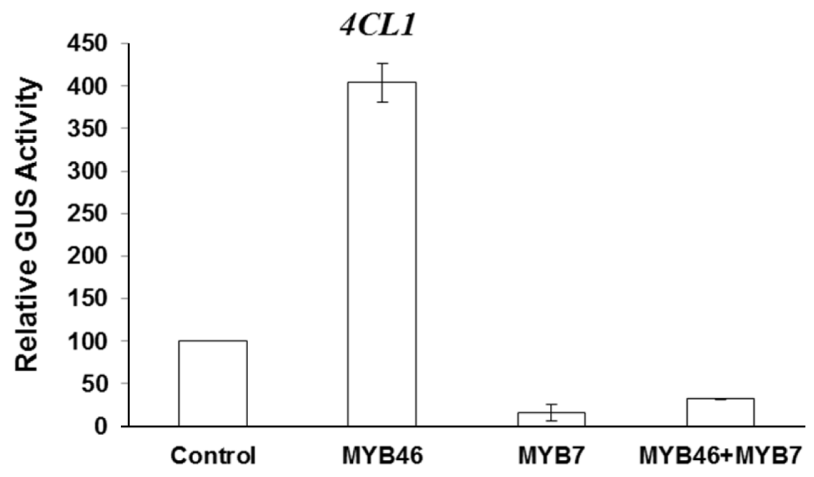

Fig. 3 MYB7 repress the expression of $4 C L 1$. MYB46 and MYB7 was expressed under the CaMV35S promoter in Arabidopsis leaf protoplasts. Activation of the $4 C L 1$ promoter by MYB46 and/or MYB7 were measured by assaying the GUS activity after $16 \mathrm{~h}$ of incubation. (A) Diagram of the effector and reporter constructs used in this analysis. (B) Transcriptional activation analysis showing the MYB7 reduced the promoter of $4 C L 1$ while MYB46 activated the promoter of $4 C L 1$. The expression level of the GUS reporter gene in the protoplasts transfected with no effector was used as a control and was set to 100. Error bars indicate STDEV of three biological replicates

(A)

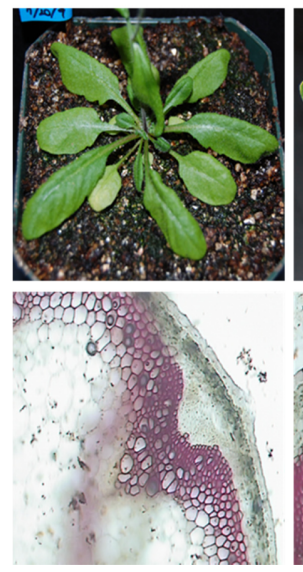

(B)

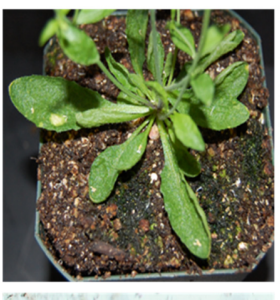

(C)
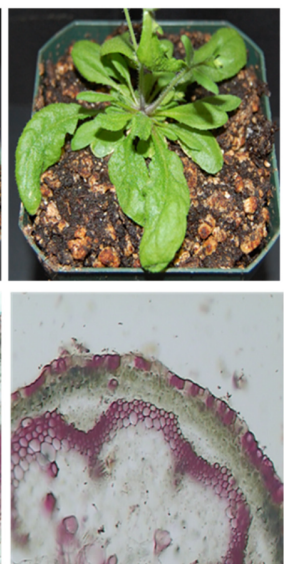

Fig. 4 Over-expression of MYB7-SRDX results in ectopic deposition of lignin in Arabidopsis plant. The 8 weeks Arabidopsis stem cross-sections were stained with Phloroglucinol- $\mathrm{HCl}$ for detection of lignin. Top, plant phenotype; Bottom, lignin histochemical staining in the Arabidopsis stem cross section. (A), wild-type (Col-0); (B), MYB7-SRDX overexpression transgenic plant; (C), MYB46 overexpression transgenic plant (positive control)

장대의 잎으로부터 protoplast를 추출하고 여기에 $\mathrm{PEG}$ 를 이용 하여 effector 벡터와 reporter 벡터를 동시에 형질전환 시켰다 (Fig. 3A). 이때 effector로는 MYB46 또는 MYB7 및 이두 전 사조절인자를 co-transformation한 것을 사용하였고 reporter로는 리그닌 생합성 유전자 중 하나인 $4 C L 1$ 유전자의 프로모터를 GUS 단백질 앞에 삽입한 것을 사용하였다. 그 결과 effector 벡 터를 넣어 주지 않고 report 벡터만 넣어준 대조 구에 비하여 MYB46 전사조절인자는 약 4배 정도의 $4 C L 1$ 유전자의 발현을 활성화시켰다 $(\mathrm{Fig}, 3)$. 흥미롭게도 MYB7 전사조절인자를 넣어 준 시험구간에서는 $4 C L 1$ 유전자의 발현을 대조 구에 비하여 9 배 이상 감소시켰으며 리그닌 생합성 유전자의 활성화 능력이 있는 것으로 보고된 MYB46 전사조절인자가 같이 들어간 구간 에서조차 대조 구에 비하여 3.5 배 이상의 $4 C L 1$ 유전자의 발현 을 감소시켰다(Fig. 3).

(A)

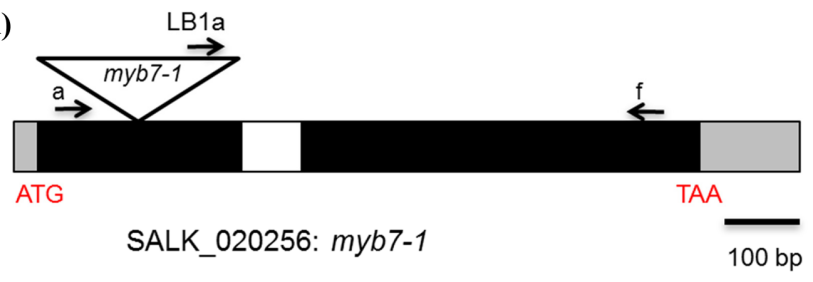

(B)

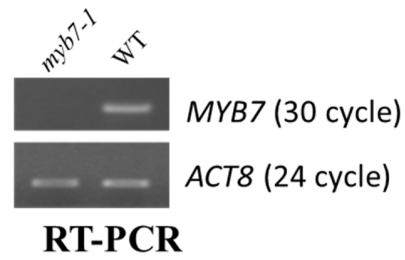

Fig. 5 T-DNA knockout mutation of $M Y B 7$. (A) Insertion site of T-DNA in the $M Y B 7$ gene. White region, intron; Black region, exon; Gray region, UTR. (B) Identification of homozygous T-DNA insertion in the myb7-1 mutant by PCR

식물의 이차세포벽 구성에 미치는 MYB7 전사인자의 영향 조사 대부분의 바이오매스는 식물에 이차세포벽에 축적된다. 상기의 실험들은 잎에서의 MYB7 전사인자의 역할을 확인한 것으로 실제 바이오매스의 축적이 일어나는 즉, 이차세포벽이 많이 생 성되는 줄기에서의 MYB7 전사인자의 역할을 확인하기 위하여 8 주 생육 된 애기장대의 줄기로부터 리그닌 함량을 조사하였다. 리그닌에 염색되는 것으로 알려진 Phloroglucinol-HCl 시약을 애 기장대 줄기의 횡단면에 염색시키고 이를 광학현미경을 통하여 관찰하였다. 그 결과 표피조직의 경우 야생형 애기장대에서는 염색되지 않았지만 MYB7-SRDX 식물체의 줄기에서는 상당히 많은 양의 리그닌 염색을 확인할 수 있었다(Fig. 4). 이는 기존 에 리그닌 생합성을 활성화하는 것으로 알려진 MYB46 전사조 절인자의 결과와 같은 것으로 MYB7 전사조절인자가 식물의 이차세포벽의 리그닌 생합성에도 관여하는 것을 증명하는 결과 로서 이를 이용하면 바이오 에탄올 발효과정에 저해 물질로 작 용하는 리그닌을 경감시킬 수 있는 기초 자료로 사용할 수 있 을 것이다. 
(A)
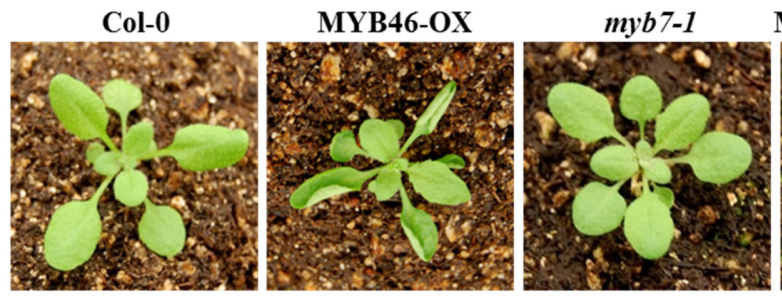

MYB46-0X/myb7-1

(B)

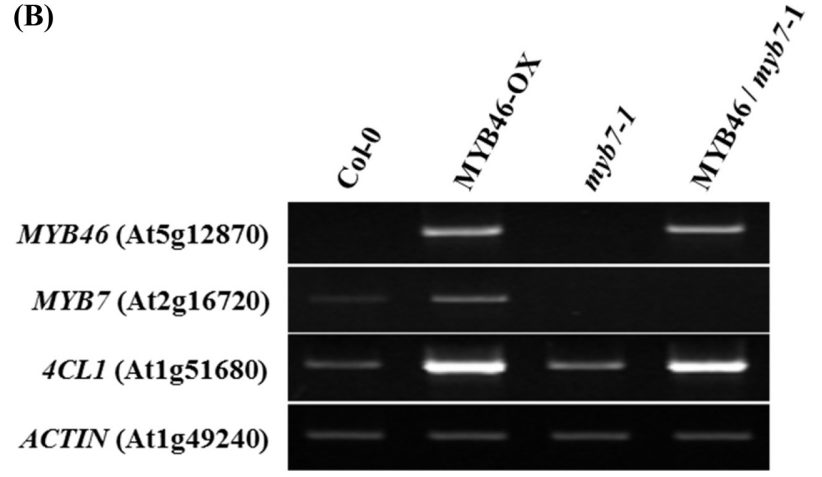

Fig. 6 MYB7 knockout mutant did not showed any phenotype. (A) Three-week-old plants. Col-0, wild-type Arabidopsis (control); MYB46-OX, MYB46 over-expression transgenic plant (positive control); myb7-1, T-DNA knockout mutations of MYB7; MYB46-OX/myb7-1, MYB46 overexpression in myb7 knockout mutant background. (B) RT-PCR showing the expression of the MYB46, MYB7 and 4CL1. Total RNAs extracted from 3week-old leaves were used in the RT-PCR. ACT8 was used as a control

MYB7 유전자의 제거에 의한 식물체내 변화 조사

MYB7 전사인자의 특성을 좀 더 살펴보기 위하여 MYB7 유전 자의 기능을 상실시킨 T-DNA가 삽입된 knockout 식물체를 $\mathrm{ABRC}$ 로부터 분양받아 실험하였다(Fig. $5 \mathrm{~A}$ ). 우선 분양 받은 종 자의 MYB7 유전자의 발현을 확인하기 위하여 RT-PCR을 실시 한 결과 MYB7 유전자의 발현 knockout 된 것임을 확인할 수 있었다(Fig. 6B). 이렇게 확인된 종자와 이 종자에 리그닌의 생 합성 활성화 능력이 있는 것으로 알려진 MYB46 전사인자를 과발현시킨 식물체의 생육을 조사한 결과 MYB7 유전자의 발 현 knockout 시킨 식물체 및 MYB7 knockout에 MYB46를 과 발현시킨 식물체에서는 특이적인 변화를 관찰할 수 없었다(Fig. $6 \mathrm{~A})$. 또한, 이들 식물체로부터 추출한 $\mathrm{cDNA}$ 를 이용하여 리그 닌 생합성에 관여하는 $4 C L 1$ 유전자의 발현 정도를 확인한 결 과에서도 특이한 변화를 관찰할 수 없었다. 이는 애기장대 내 에 MYB7 전사조절인자의 역할을 대신해줄 수 있는 다른 전사 인자(MYB4 및 MYB32)에 기인한 것으로 사료된다. 종합적으 로 상기의 결과들로부터 애기장대의 MYB7 전사조절 인자는 식물의 구성성분 중 하나인 리그닌의 생합성을 억제 조절하는 것으로 판단되며 좀 더 구체적인 연구를 진행한다면 에너지 작 물 개발 분야에서는 저 리그닌 또는 추출이 쉬운 리그닌을 가 진 작물의 개발 및 효소들이 쉽게 접근이 가능한 작물 개발의 기초 자료로 사용될 수 있을 것이다.

\section{초 록}

식물의 이차생장의 결과로 생산되는 바이오매스의 대부분은 식 물의 이차세포벽에 축적된다. 식물의 이차세포벽은 크게 셀룰로
스, 헤미셀룰로스, 리그닌이라는 3 가지 물질로 구성되며 이들 중 페놀성 복합 화학 물질인 리그닌은 셀룰로스나 헤미셀룰로 스와 달리 알코올 발효과정의 저해 물질로이다. 따라서, 식물의 이차세포벽 생합성의 과정을 조절함으로 전체 바이오매스의 생 산량과 조성을 바이오 에너지 생산을 위해 최적 조건으로 조절 함으로써 바이오 에탄올 생산을 최대화할 수 있을 것이다. 본 연구에서는 애기장대 유래 MYB7 유전자를 CaMV35S 프로모 터 조절 하에서 과별현되게 한 식물체와 식물의 전사조절에서 하위 특정 유전자의 발현을 저해시키는 것으로 잘 알려진 $\mathrm{SRDX}$ 융합 단백질 즉, MYB7-SRDX 과발현체를 제작하여 그 특성을 조사하였다. 그 결과 MYB7 전사조절 인자가 리그닌의 생합성을 억제 조절한다는 결과를 관찰하였다. 이는 MYB7 전 사조절인자를 이용하면 바이오 에탄올 발효과정에 저해 물질로 작용하는 리그닌을 경감시킬 수 있는 기초 자료로 사용할 수 있을 것이다.

Keywords 바이오에탄올 - 리그닌 - 식물이차세포벽생합성 - 전 사조절

감사의 글 이 논문은 2015학년도 경북대학교 신임교수정착연구비에 의하 여 연구되었음.

\section{References}

Alvira P, Tomás-Pejó E, Ballesteros M, Negro M J (2010) Pretreatment technologies for an efficient bioethanol production process based on enzymatic hydrolysis: A review. Bioresour Technol 101: 4851-4861

Himmel ME, Ding SY, Johnson DK, Adney WS, Nimlos MR, Brady JW, 
Foust TD (2007) Biomass recalcitrance: engineering plants and enzymes for biofuels production. Science 315: 804-807

Jin H, Cominelli E, Bailey P, Parr A, Mehrtens F, Jones J, Tonelli C, Weisshaar B, Martin C (2000) Transcriptional repression by AtMYB4 controls production of UV-protecting sunscreens in Arabidopsis. EMBO J 19(22): 6150-6161

Kagale S, Rozwadowski (2011) EAR motif-mediated transcriptional repression in plants: an underlying mechanism for epigenetic regulation of gene expression. Epigenetics 6(2): 141-146

Kang Q, Apples L Tan T, Dewil Raf (2014) Bioethanol from Lignocellulosic Biomass: Current Findings Determine Research Priorities. Scientific World J 31: 2014:298153

Kim WC, Kim JY, Ko JH, Kang H, Han KH (2014) Identification of direct targets of transcription factor MYB46 provides insights into the transcriptional regulation of secondary wall biosynthesis. Plant Mol Biol 85(6): 589-599

Kim WC, Ko JH, Kim JY, Kim J, Bae HJ, Han KH (2013) MYB46 directly regulates the gene expression of secondary wall-associated cellulose synthases in Arabidopsis. Plant J 73(1): 26-36

Ko JH, Kim WC, Han KH (2009) Ectopic expression of MYB46 identifies transcriptional regulatory genes involved in secondary wall biosynthesis in Arabidopsis. Plant J 60(4): 649-665

Ko JH, Yang SH, Park AH, Lerouxel O, Han KH (2007) ANAC012, a member of the plant-specific NAC transcription factor family, negatively regulates xylary fiber development in Arabidopsis thaliana. Plant J 50(6): 1035-1048

Kubo M, Udagawa M, Nishikubo N, Horiguchi G, Yamaguchi M, Ito J, Mimura T, Fukuda H, Demura T (2005) Transcription switches for protoxylem and metaxylem vessel formation. Genes Dev 19(16): 18551860

Seo HB, Han JG, ChoiWS, Lee OK, Lee SM, Choi SH, Lee HY, Jung KH (2008) Bioethanol production from wood biomass hydrolysate with supercritical water treatment. Korean J Biotechnol Bioeng 23(6): 494 498

Xiang C, Han P, Lutziger I, Wang K, Oliver DJ (1999) A mini binary vector series for plant transformation. Plant Mol Biol 40(4): 711-717

Zhong R, Richardson RA, Ye ZH (2007) The MYB46 transcription factor is a direct target of SND1 and regulates secondary wall biosynthesis in Arabidopsis. Plant Cell 19(9): 2776-2792 